\title{
Need Analysis: Development of LK-D\&T Sketch Module for Form One Design and Technology (D\&T) Subject in Secondary School
}

\author{
Nor Anisah Ahmad', Ridzwan Che Ros ${ }^{1}$, Arasinah Kamis', Hawa Naqiah Makmor ${ }^{2}$ \\ ${ }^{1}$ Universiti Pendidikan Sultan Idris, 35900 Tanjong Malim, Perak, Malaysia \\ ${ }^{2}$ Sekolah Menengah Sains Muzaffar Syah, Ayer Keroh, Melaka, Malaysia \\ *Corresponding author, e-mail: ridwan@ftv.upsi.edu.com.my
}

\begin{abstract}
This study is a need analysis of the development of sketch module for secondary D\&T students. This study is in a form of a survey using questionnaire as a research instrument. A total of 287 teachers were involved in the study sample. The study sample was randomly selected. The data were analyzed using a descriptive analysis to meet the objectives of the study. The findings show that teachers are facing difficulties in implementing D\&T teaching in schools. The majority of teaching teachers consist of non-option D\&T teachers, lack of D\&T knowledge and skills, intensive course requirements, less teaching aids and less conducive workshops. Students found that it was difficult to master topics that the teachers teach, especially the topic of sketching. The majority of teachers agree that the topic of sketching ought to be developed in a way to enhance students understanding, and along with helping the less skilled teachers. The implication of the study is that this module can be used by D\&T teachers and students as a reference to improve the teaching and learning to become more effective.
\end{abstract}

Keywords: Design and technology, Need analysis, Sketching module.

\section{INTRODUCTION}

Need analysis is a first step to implement the changes in educational environments to determine the gaps between the current and desired conditions. According to McArdle (1998), the process of need analysis is a series of activities carried out to identify problems in the classroom or workplace, and to determine whether there is a requisite of improvement in teaching or training to be conducted. Evangeline \& Ganesh (2016) defines need analysis as activities that used to gather information about student learning needs. The purpose of teaching needs analysis is to identify the gaps that exist between existing needs and consumer needs. This kind of analysis is able to find solutions, correct deficiencies that exist in terms of knowledge or skills, and to obtain information from teachers who are the users of this module. The information on teacher teaching is based on the feasibility of the module, which is from masses of aspects such as requirements, teaching practices and the problems encountered in executing the learning. In the context of module development, identifying problems through needs analysis, goal analysis and performance analysis is the first step (Morrison, Ross, \& Kemp, 2007). Isman (2011) proposes that process of building a module begins with a few steps including: identification of needs, identification of objectives, defining teaching methods and defining media intrusion.

\section{Design and Technology}

Design and technology are inspiring, rigorous and practical subjects. By using creativity and imagination, pupils could design and create products that will solve real and relevant problems within a variety of contexts, considering their own and others' needs, wants and values. They acquire a broad range of subject knowledge and draw on disciplines such as mathematics, science, engineering, computing and art. Pupils then learn how to take risks, becoming resourceful, innovative, enterprising and capable citizens through the evaluation of past and present designs. 
Moreover, in Malaysian blue print 2013-2025, it has introduced design and technology (D\&T) subjects to replace life skills subjects in all secondary schools in Malaysia, Design and technology main focus is on mastery of knowledge (cognitive), skills (psychomotor) and values and attitudes (affective) to suit students' level of competence based on content standards and learning standards. Students are learned to use and adapt with the current technologies while keeping an open mind to consider the impact of future technological developments (Huei, Rus \& Kamis, 2019). They learn to think creatively and to inverse when there is an opportunity to improve the quality of life. Problems are solved as individuals as well as members of a team. Students are also being taught to develop their design and technology capability by combining their design and making skills with their knowledge and understanding in order to produces real products with real-life benefits.

Meanwhile, a study concluded by Alwi \& Kamis (2019) which used the ADDIE model to develop a Green Skills (Gs) teaching module for D\&T subjects to enhance teaching and facilitate the process to a greater degree.

\section{Necessities of Module Development}

Design and Technology is a new subject in the Malaysian secondary school curriculum. This subject requires very different approaches to teaching and learning by both teachers and students, compared to conventional classroom approaches, to realize the full potential of Design and Technology. The need to gain a deeper understanding of the current subject and the difficulties encountered in teaching this subject have prompted researchers to conduct disciplinary research into it.

Currently, the education system in Malaysia requires teachers to be as a mentors to the students so that students will possess skills to think, solve problems, communicate and collaborate with people. Furthermore, teachers should face the challenges positively in order to gain knowledge and skills for self-enrichment and enhancement to apply these skills in the classroom. Unfortunately, the implementation of D\&T subjects in Malaysian high school is now moderately alarming, the findings from Huei, Rus \& Kamis, (2019) found that $90 \%$ of D\&T teachers faced the biggest challenge in teaching and learning because of scarceness in content of knowledge, mastery, and skill, also due to lack of experiences. This strikingly occurred because of the teachers retain of teaching a non-option subject in school, besides, preponderance of them were living skills teachers.

Furthermore, a study done by Ali (2000) found that teachers need to have expertise in various aspects such as mastery of the content areas, mastering the teaching methods and manage student's discipline, so that teaching and learning process can be affected smoothly. Salwa (2016) pointed out that teachers' success as a leader will be reflected in their ability to make changes in the classroom through collaboration with students towards the achievement of teaching and learning goals. One who is able to plan, give directions, control the process and develop strategies to achieve the desired goals is rightly proficient in the role of teacher leadership. Therefore, leaders must be able to change subordinate behavior or attitude to relocate towards achieving the defined goals.

Moreover, a study from Salwa (2016) found that there is a significant difference between perceptions of teaching skills and student achievement amid the teachers in options and non-options subject of Living Skills. This clearly shows that teachers are indispensable to master the skills and knowledge, even though they are prepared and interested to teach, owing to realise the teaching and learning objectives in the classroom by using a variety of resources and taking intensive courses. In contrast, a study by Puteh et al. (2012) who found that non-option teachers were not confident while teaching nonoptions subjects has led students to ensue less motivated and consequently decreased their

Ahmad, N. A., Ros, R. C., Kamis, A., \& Makmor, H. N. (2019). Need Analysis: Development of LK-D\&T Sketch Module for Form One Design and Technology (D\&T) Subject in Secondary School. Journal of Vocational Education Studies, 2(2), 75-82. DOI: https://doi.org/10.12928/joves.v2i2.708. 
performance in class. Therefore, teachers need to brainstorm to find other initiatives in regard to teaching, using the latest sources of references as well as using interesting teaching aids.

Next, a study driven by Baharen et al. (2011) found that theoretical knowledge and expertise in specific skills taught in the classroom should have important elements pertaining to a particular topic of learning, imputable to ensure that all planned objectives are met. In addition, teachers need to apply the latest and more effective teaching techniques in order to attract attention of students in class. Consequently, students will feel much happier, fun and able to master the knowledge and skills they need. This is because, according to Idris (2010), teachers are considered holding competence in their respective fields in order to develop students' skills, talents, potential and knowledge in various forms. Truth is that, the success of the learning process that furnished by teachers and experienced by students in the classroom is measured by student achievements. A study by Booth et al. (2016) testified that incorporated in systematic and intensive trainings such as sketch training will produce more effective effects in short term.

Matanluk et al. (2013) studied on the application of the module of geography teaching has enhanced thinking skills as one of the student-centered approaches. In addition, a research executed by Kempton et al., (2018); Alwi \& Kamis (2019); Ismail et al. (2018) depict that the use of education module has benefited students by generating create effective, engaging, student-centered activities and help students more effectively. In the context of this study, the needs analysis was conducted to identify the problems and needs of teachers in implementing D\&T subject in secondary schools. The results and suggestions obtained in the analysis phase are then used in the next phase of the design and development of the module.

The main objectives of this study are: (1) identifying the main problems teachers face in teaching and learning D\&T subjects; (2) identifying the need for teachers to enhance teaching and learning in D\&T subjects in secondary school; (3) identifying module development needs for topics in D\&T syllabus.

\section{RESEARCH METHOD}

The researcher opted to carry out quantitative research in which the data were collected through a survey. This study referred to McKillip (1987) for needs analysis which is the first step to identify the causes and solutions of problems and learning needs that are utilized in one teaching system. The researcher used the questionnaire as a research instrument. The questionnaire consisted of 3 sections, namely, (1) demographics, (2) problems in teaching and learning, (3) needs and suggestions for improvement. The instruments validity procedures were implemented in this study which recognized as face validity and content validity. Four specialists have been selected, from two language experts to face validity and two principal technologists (JU) in design and technology (D\&T). Furthermore, the feedbacks from all the experts helped researcher to develop the questionnaire. The population of 6422 people for this study consisted of teachers that are teaching D\&T subject throughout Malaysia. A simple random sampling was used to select the 287 teachers involved in the study sample. Questionnaires were distributed and data were analyzed using descriptive analysis to obtain mean and percentage scores to answer the research questions entirely.

\section{RESULTS AND DISCUSSION}

Table 1 shows the findings for the demographics of the respondents. These findings show that teachers with D\&T options were only $3 \%$, while $30.8 \%$ were from home science

Ahmad, N. A., Ros, R. C., Kamis, A., \& Makmor, H. N. (2019). Need Analysis: Development of LK-D\&T Sketch Module for Form One Design and Technology (D\&T) Subject in Secondary School. Journal of Vocational Education Studies, 2(2), 75-82. DOI: https://doi.org/10.12928/joves.v2i2.708. 
(ERT) options, followed by entrepreneurships options which $26.4 \%$, agriculture options that $25 \%$, and technical skills (KT) of $17.6 \%$. Finding on teaching experience found that most of Malaysian teachers had more than 6 years teaching experience of $85.39 \%, 27.9 \%$ served 6 to 10 years, $22.1 \%$ served 11 to 15 years, $17.6 \%$ served 16 to 20 years, $10.3 \%$ served 21 to 25 years and $7.49 \%$ served 26 to 30 years. The survey shows that $14.7 \%$ of teachers work for 1 to 5 years. This indicated that the majority of teachers were from living skills teachers who had more than 6 years of experience in effectively implementing their curriculum or selected option. Any changes to a new curriculum implementation will take extra time for them to master it.

Table 1. Demography

\begin{tabular}{lll}
\hline Items & & Percentage \\
\hline Optionist subject & D\&T & 3 \\
& Home Science & 30.8 \\
& Technical Skills & 17.6 \\
& Entrepreneurships & 26.4 \\
Teaching experience & Agriculture & 25 \\
& $1-5$ years & 14.7 \\
& $6-10$ years & 27.9 \\
& $11-15$ years & 22.1 \\
& $16-20$ years & 17.6 \\
& $21-25$ years & 10.39 \\
& $26-30$ years & 7.4 \\
\hline
\end{tabular}

\section{Objective 1: Identify the main problems teachers face in teaching and learning D\&T subject}

Table 2 shows the findings on the main problems faced by teachers in teaching and learning D\&T. Findings show that the majority of teachers which were over $80 \%$ had trouble in mastering the content knowledge, lack of skills and less training were appertained to D\&T content and subject matter skills. $63.5 \%$ of them also agreed that the existing workshops were not suitable for the teaching and learning process. Meanwhile, the other problems were lack of referrals, teaching aids such as modules at $77.6 \%$ and the problem of allocation budgets from the government was found to be insufficient for material requirements and more was about $45.6 \%$. Further, they stated that teachers had situation that lack of reference materials, modules $63.2 \%$ and existing workshops did not suitable was $50 \%$. As for solution, they choose to have $92.6 \%$ intensive training or courses, increase the teaching aids $75 \%$, and upgrade the workshops $73.5 \%$.

Table 2. Main problems in Teaching and Learning D\&T subject

\begin{tabular}{ll}
\hline Items & Percentage \\
\hline Lack of content knowledge & $88.8 \%$ \\
Lack of skills & $86.2 \%$ \\
Less training & $87.2 \%$ \\
Lack of referrals/teaching aids & $77.6 \%$ \\
Workshop are not suitable & $63.7 \%$ \\
Not enough budget from the government & $45.8 \%$ \\
\hline
\end{tabular}

Ahmad, N. A., Ros, R. C., Kamis, A., \& Makmor, H. N. (2019). Need Analysis: Development of LK-D\&T Sketch Module for Form One Design and Technology (D\&T) Subject in Secondary School. Journal of Vocational Education Studies, 2(2), 75-82. DOI: https://doi.org/10.12928/joves.v2i2.708. 


\section{Objective 2: Identify the need for teachers to enhance teaching and learning in D\&T subjects in secondary school}

Table 3 shows the titles or topics that students discovered as difficult to master in D\&T subjects. Findings show that $67.6 \%$ of teachers agreed that sketching was a the most difficult topic for students, followed by Project Management and Design Process of $38.2 \%$, followed by $14.7 \%$ Fertility system design, 11.8\% D\&T introduction and $8.8 \%$ fashion design. Sketches are a topic that is found in all topics in D\&T syllabus. Therefore, with the lack of mastery in the sketch topic by students, the teaching and learning processes will be affected and results to negative consequences.

Table 3. Student mastery level

\begin{tabular}{lll}
\hline Items & & Percentage \\
\hline Difficult topics to master & D\&T introduction & $11.8 \%$ \\
to master & Project management & $38.2 \%$ \\
& Design process & $38.2 \%$ \\
& Sketching & $67.6 \%$ \\
& Fertility system design & $14.7 \%$ \\
& Fashion design & $8.8 \%$ \\
\hline
\end{tabular}

Objective 3: Identify module development needs for topic in D\&T syllabus for Form 1

Table 4 refers to the needs of module development by topics, it was found that most of teachers agreed that all topics need appropriate and systematic activities such as modules. The majority of teachers agreed with $89.6 \%$ for the Sketch module to be developed to facilitate D\&T teaching and learning process for sketch topic. Subsequently, findings from this section found that module is also needed for other topics such as $41.7 \%$ fertility system design, $36.8 \%$ fashion design, $31.8 \%$ introduction, project management $20.2 \%$ and design process $18.2 \%$.

Table 4. Needs of module development by topics

\begin{tabular}{ll}
\hline Items & Percentages \\
\hline Introduction of D\&T & $31.8 \%$ \\
Project management & $20.2 \%$ \\
Design process & $18.2 \%$ \\
Sketch & $89.6 \%$ \\
Fertility system design & $41.7 \%$ \\
\hline
\end{tabular}

\section{Discussion}

The needs analysis study is the first step that need to be carried out before the module design and development process is could be implemented. The main interest in the analysis of these needs is to determine the need for module development based on the questionnaire on towards the teachers who were teaching D\&T in secondary school. The result of the need analysis found that most of the teachers who teach D\&T are from non-option teachers. Therefore, they faced problems in mastering their content knowledge, skills and also due to lack of learning resources. The findings of this study are in line with the findings of Huei, Rus, \& Kamis (2019), Salwa (2016), and Puteh et al. (2012) that found 90\% of respondents expressed the biggest challenge that they have to face is the lack of experience and teaching a non-optionist subject, low in knowledge and skills to teach D\&T subject. Therefore, teachers need to have expertise in the areas taught, mastering the teaching method as suggested by Ali (2000). In addition, Salwa (2016) suggested that teachers should be 
leaders who are capable of planning, giving direction, controlling the process and developing strategies to achieve the goals.

\section{The need for teachers to enhance the learning and teaching of D\&T subjects in secondary school}

The findings of the study is to identify teachers' needs in enhancing D\&T learning and teaching in schools found that most of teachers hoped that intensive courses would be augmented especially for topics involving specific skills such as Design and Design projects. This is in line with the study by Baharen et al., (2011) who stated that theoretical knowledge and expertise in the skills taught should be the important element to ensure that all the objectives to be achieved. Thus, they have agreed that schools, state education department or the state education itself should provide more intensive courses and training, teaching and learning. This is important in an effort to enhance their understanding, knowledge and skills in D\&T subjects (Amri et al., 2019). Other suggestions that laid down by teachers are to include more resources such as modules, reference books and others that will help them to improve the teaching and learning process in the classroom. Some of them also stated that the existing workshops, less practical for teaching and learning of D\&T, and by improving the workshops it would enhance their comfort in the process of teaching and learning is being conducted.

\section{Module development needs for topics in D\&T}

This is followed by other topics such as D\&T introduction, project management, fertility system, design process and fashion design. This finding is in line with the findings of Huei, Rus, \& Kamin (2019) that $81 \%$ of respondents stated that the competency and proficiency of the students are at a low level. Teacher manual that issued by the Ministry of Education Malaysia towards teachers is among the most efficient guidance such as D\&T modules that available in the market. However, after examining the materials, it is found that there is little emphasis on the topic of sketches in the module. The result of document analysis, attested that the modules available are in the form of knowledge questions, did not lead/focus to the development of sketch skills. Consequently, it still did not help teachers to implement in effective means of teaching and learning.

The results from interviews with several teachers indicated that they are still looking further for a module that specializes in sketching clearly, comprehensively and easily for those who are not proficient in the field. This clearly shows that from the need analysis result, the need to develop sketching module in detailed, structured and follow the level of sketch learning module was absolutely significant. Sketch's skills are difficult for students to master, so teachers need to boast the knowledge and skills of sketch in impeccable sense to develop those skills accordingly. Good results will be developed from intensive training, systematic exercises such as Booth et al. (2016) findings suggested that sketch training and inhibition reducing exercises were effective in short term, but it must be emphasized over time to turn as a permanent change.

The use of modules in learning is seen to enhance students' knowledge and skills. This study is commensurate with a study by Matanluk et al. (2016) who studied about the implementation of module of Geography Teaching Module. He stated that the implementation of the module targeted increased thinking skills as the use of studentcentered approach. Kempton et al. (2018), Alwi \& Kamis (2019); Ismail et al. (2018) then demonstrated that, the use of an education module demonstrated a significant benefit to the students and demonstrate better familiarity with the equipment's and equivalent performances of procedure. This finding distinctly depicts the efficiency of using modules

Ahmad, N. A., Ros, R. C., Kamis, A., \& Makmor, H. N. (2019). Need Analysis: Development of LK-D\&T Sketch Module for Form One Design and Technology (D\&T) Subject in Secondary School. Journal of Vocational Education Studies, 2(2), 75-82. DOI: https://doi.org/10.12928/joves.v2i2.708. 
can construct better effectiveness, and engagements by students, ameliorate studentcentered activities. Other module studies also found positive results from the use of modules during teaching and learning process such as affirmed in the, studies from Sakir \& Atan (2007), Sarjan (2014), and Aziri \& Ahmad (2016). They found that the use of the module in teaching and learning process is proved to be effective in increasing student' achievements.

\section{CONCLUSION}

This study focused on needs analysis for development of sketching learning module for D\&T students in secondary school. There is no learning module developed in this study. The study was conducted in a Malaysian cultural context. The limitation of this study is that the non-optionist teachers encountered voluminous difficulties in teaching D\&T subject in secondary school. Hence, researchers have considered to administer the questionnaire method with respect to go in-depth their real needs and problems in teaching D\&T by the teachers. Furthermore, the researchers suggested to develop a sketching module based on the needs analysis conducted. The implications of this study will contribute to the Ministry of Higher Education Malaysia, University, and educators in order to develop curriculum or learning modules, especially to enhance skill in sketching in design and technology.

\section{REFERENCES}

Ali, W. Z. W. (2000). Memahami Pembelajaran. Kuala Lumpur: Utusan Publication.

Alwi, A., \& Kamis, A. (2019). Using The ADDIE Model to Develop Green Skills Teaching Module. International Journal of Engineering Research and Applications, 9(1), 53-57.

Amri, A. N., Azman, M. N. A., Kiong, T. T., \& Khairudin, M. (2019). Keberkesanan Alat Bantu Mengajar (SMART COT) dalam Asas Pembuatan Perabot Sekolah Menengah Kebangsaan Harian Pendidikan Khas Tingkatan Satu. Journal of Vocational Education Studies, 2(1), 23-36.

Aziri, S. S. M., \& Ahmad, C. N. C. (2016). Penggunaan modul pembelajaran dan pengajaran berasaskan analogi terhadap pencapaian pelajar bagi topik enzim dalam Biologi tingkatan 4. Tesis Sarjana. Tanjong Malim: Universiti Pendidikan Sultan Idris.

Baharen, K., Luaran, J. E. \& Mohamed, Z. (2011). A Study on the Level of Skills and Perceptions Towards Information Technology Among Primary School Teacher in Pitas District Malaysia. National Academic Conference (ENRICH 2011). Kelantan: Universiti Teknologi MARA.

Booth, J. W., Taborda, E. A., Ramani, K., \& Reid, T. (2016). Interventions for teaching sketching skills and reducing inhibition for novice engineering designers. Design Studies, 43, 1-23.

Evangeline, J. C. K., \& Ganesh, K. (2016). A need analysis of technical writing skill of engineering students in India. In SHS Web of Conferences (Vol. 26, p. 01090). EDP Sciences.

Huei, O. K., Rus, R. C., \& Kamis, A. (2019). Need Analysis: Competency Development Measurement Instrument in Mastering the Content of Design and Technology Subject in High School. International Journal of Academic Research in Business and Social Sciences, 9(6), 1043-1052.

Idris, N. (2010). Penyelidikan dalam Pendidikan. Kuala Lumpur: McGraw Hill Sdn. Bhd.

Ismail, B. L., Kamis, A., Alwi, A., \& Kob, C. G. C. (2018). Application of Fuzzy Delphi Methods in Developing of Green Skills Elements in Secondary Schools. Sains Humanika, 10(3).

Ahmad, N. A., Ros, R. C., Kamis, A., \& Makmor, H. N. (2019). Need Analysis: Development of LK-D\&T Sketch Module for Form One Design and Technology (D\&T) Subject in Secondary School. Journal of Vocational Education Studies, 2(2), 75-82. DOI: https://doi.org/10.12928/joves.v2i2.708. 
Isman, A. (2011). Instructional Design in Education: New Model. Turkish Online Journal of Educational Technology-TOJET, 10(1), 136-142.

Kempton, S. J., Salyapongse, A. N., Israel, J. S., \& Mandel, B. A. (2018). Surgical education module improves operative proficiency in endoscopic carpal tunnel release: A blinded randomized controlled trial of trainees. Journal of Surgical Education, 75(2), 442-449.

Matanluk, O., Mohammad, B., Kiflee, D. N. A., \& Imbug, M. (2013). The effectiveness of using teaching module based on radical constructivism toward students learning process. Procedia-Social and Behavioral Sciences, 90, 607-615.

McArdle, G. (1998). Conducting a needs analysis: A fifty minute book. Boston: Course Technology Crisp.

McKillip, J. (1987). Need analysis: Tools for the human service and education. Applied Social Research Methods Series.

Morrison, G.R., Ross, S.M. \& Kemp, J. E. (1987). Designing Effective Instruction. Hoboken: John Wiley and Sons, Inc.

Puteh, M., Ibrahim, M. H., Adnan, M., Che'Ahmad, C. N., \& Noh, N. M. (2012). Thermal comfort in classroom: constraints and issues. Procedia-Social and Behavioral Sciences, 46, 1834-1838.

Sakir, N. S., \& Atan, N. A. (2007). Penambahbaikan Rekabentuk Modul Pembelajaran kendiri Bagi Perisian Microsoft Frontpage Xp 2003. Doctoral Dissertation. Johor: Universiti Teknologi Malaysia.

Salwa, S. (2016). Teachings of optionist and non optionist primary school teachers of living skill in Batu Pahat. Journal of Global Business and Social Entrepreneurship, 2(2), 153162.

Sarjan, F. (2014). Kesan penggunaan modul pembelajaran sains tingkatan dua. Tesis Sarjana. Johor: Universiti Tun Hussein Onn Malaysia. 